\title{
[Safe] in a Narcissistic Closure
}

\author{
Narsistik Kapanmada Güvende \\ Defne Tüzün, Department of Radio, Television ve Cinema, Kadir Has University
}

\begin{abstract}
This article offers an in depth formal analysis of the film Safe (Todd Haynes: 1995) By attending to Julia Kristeva's concept of abjection as the earliest attempts to demarcate a space in the common, indistinguishable territory of the mother-child dyad and as an endeavor to overcome spatial ambivalence, this analysis focuses on the topography of the pre-symbolic. The study deals primarily with the film's protagonist, Carol's abjection, as evidenced by her relation to corporeality and to spatiality. Carol goes through a crisis in life and suffers from an undiagnosed illness. As the film progresses, she goes to a healing facility out in the desert, where she seeks treatment for her disease, here, but gradually regresses to a narcissistic phase. The semi-religious philosophy of this facility leads her to isolate herself from society and negates her integration into the socio-symbolic network. This self-indulgence and self-love finally causes her to be trapped in a narcissistic closure. This article discusses this narcissistic closure through the visual and audio analysis of the film.
\end{abstract}

Keywords: Safe, Todd Haynes, abjection, Julia Kristeva, narcissism, maternal, corporeality.

Academical disciplines/fields: Film studies, psychoanalysis, narratology.

\section{Özet}

Todd Haynes'in Safe (1995) filminin biçimsel bir analizini sunan bu makale Julia Kristeva'nın iğrenme (abjection) kavramından hareketle filmin baş karakteri olan Carol'un bedensel ve mekânsal olanla ilișkisini ele almaktadır. Makale, Kristeva'nın kavramsallaștırmasında olduğu gibi, iğrenme anne-çocuk simbiyozunun yarattığı bir uzamsal muğlaklık ve öznenin anne çocuk simbiyozunun dıșına çlkıp kendi alanını kurma mücadelesi olarak yorumlayarak Carol karakterinin bir tür iğrenme deneyiminden geçtiğini savunmaktadır. Filmin anlatısında Carol tanısı konamayan bir hastalığa tutulmuştur ve bir kriz yașamaktadır. Bu krizle baș edemeyince çölün ortasında bir șifa merkezine gidip burada yaşamaya başlar. Yarı dini bir felsefeye sahip bu merkez Carol'un kendini toplumdan tamamen izole etmesine ve sosyal sembolik düzenle olan bağını koparmasına neden olur. Makale karakterin bu narsistik kapanma sürecini filmin görsel ve işitsel yapısını analiz ederek tartışmaktadır.

Anahtar Sözcükler: Safe, Todd Haynes, iğrenme, Julia Kristeva, narsisizm, annelik, bedensellik.

Akademik disipin(ler)/alan(lar): Film çalışmaları, psikanaliz, naratoloji.

- Corresponding Author: Defne Tüzün, Radyo, Televizyon ve Sinema Bölümü, İletișim Fakültesi, Kadir Has Üniversitesi.

- $\quad$ Address: Kadir Has Üniversitesi, Kadir Has Cd., 34083 Cibali ,Fatih, İstanbul.

- $\quad$ e-mail: defne.tuzun@khas.edu.tr

- ORCID: 0000-0001-5548-1866

- $\quad$ Available online: 13.11 .2021

- doi: $10.17484 /$ yedi.963673 


\section{Introduction}

The film Safe (1995) enables us to discuss Julia Kristeva's conceptualization of abjection as the earliest attempts to demarcate a space in the common, indistinguishable territory of the mother-child dyad and as an endeavor to overcome "spatial ambivalence (inside/outside uncertainty)" (Kristeva, 1982, p. 62). I open this discussion by articulating the distinctive spatio-temporal topology within which abjection is situated. In Powers of Horror: An Essay on Abjection, Kristeva (1982, p. 10) defines abjection by placing a special emphasis on the maternal: "abjection preserves what existed in the archaism of pre-objectal relationship". When the topology of the mother-child dyad-this primordial relationship-is concerned, the distinction between consciousness and unconsciousness is irrelevant; object and subject crumble. Kristeva formulates her concept of abjection as the earliest trials of separation. She states, "The abject confronts us [...] within our personal archeology, with our earliest attempts to release the hold of maternal entity even before existing outside of her, thanks to the autonomy of language" (Kristeva, 1982, p. 13). Abjection emerges in this peculiar topology, in the symbiotic space shared by the indistinguishable bodies of the mother and the child. A primordial struggle for separation, abjection sets in even as the infant is within the 'maternal entity' that is, prior to birth.

When the abject confronts the infant, its corporeal boundaries are non-distinctive; inside and outside are not differentiated. The infant abjects the mother's body in order to be; to differentiate from the very maternal receptacle in which it dwells; at this moment, the ego of the infant is not yet a subject, and the mother is not yet an object. In Julia Kristeva: Psychoanalysis and Modernity, Sarah Beardsworth (2004, p. 84) explains that "the abjection of the mother's body" needs to be considered "as a semiotic capacity for turning the maternal container into a maternal 'space' from which subject-to-be may separate." Here it is important to note that by assigning a semiotic or pre-verbal capacity to the being that is not yet registered in the symbolic order, Kristeva refuses to identify the semiotic receptacle with the mother's body. The abjection of the maternal is the necessary condition whereby the ego of the infant emerges and the mother is established as the object of that ego. The abject, in Kristeva's (1982, p. 2) words, is the "jettisoned object" that is excluded from the mother's body, not equivalent to it. The abject is an unstable border, the in-between that makes the (subsequent) correlativeness of subject and object possible.

\section{2. [Safe] in a Narcissistic Closure}

This paper analyses $S a f e^{1}$ by attending to Kristeva's concept of abjection as it relates to corporeality, borders and the maternal. The film foregrounds and problematizes the protagonist's subject formation and her relation to corporeal borders. At the beginning, the protagonist, Carol, is presented to be neat, tidy, well-composed and orderly and yet beset by abjection she gives into attacks of corporeal, she loses her control over her body. Throughout this article, I analyze specific scenes and their narration-wise strategies in detail, discuss where and how Carol has attacks and the ways in which these scenes reveal her troubles with corporeality and maternal, pointing at her experience of abjection. Furthermore, I argue that Safe points to the melancholic disposition of the protagonist. By hiding the reasons behind Carol's disturbances, the film represents her as someone who does not have an insight into what she is wailing over or what she is mourning for. Safe's portrayal of Carol as melancholic resonates well with the psychoanalytical conceptualization of this psychic formation. Freud proposes that melancholy is marked by the subject's ambivalent relationship to its love object. In Mourning and Melancholia, as Freud clarifies:

[T] he occasions which give rise to [melancholia] extend for the most part beyond a clear case of a loss by death, and include all those situations being slighted, neglected or disappointed, which can import opposed feelings of love and hate into the relationship or reinforce an already existing ambivalence (Freud, 1917, p. 260).

By comparing the dynamic mechanisms of mourning and melancholia, Freud (1917, p. 253) emphasizes that melancholia shares the essential characteristics of mourning, as both mechanisms involve "a reaction

\footnotetext{
${ }^{1}$ In her article, "Of Housewives and Saints: Abjection, Transgression, and Impossible Mourning in Poison and Safe" Laura Christian gives a comparative analysis of Haynes's two films: Poison and Safe. In her analysis, Christian draws on Kristeva's Powers of Horror and gives a brief account of the protagonist's subjecthood and her trials with abjection. However, rather than delving into the protagonist's psychosexual positioning and problems, Christian takes up the issue of abjection at a societal level. Christian's analysis relies heavily on the way Haynes's films can be read in relation to AIDS discourses. Within this context, she suggests that Haynes's work reveals the parallel between the experiences of women and gay men. This parallelism, she argues, should not be regarded as a "metaphoric" but as "metonymic". She writes: "That is to say, it does not so much suggest an analogical relation between the condition of femininity and that of male subjectivity 'at the margins,' but instead outlines their interfaces and the foreclosures on which each is founded" (Christian, 2004, p. 95).
} 
to the real loss of a loved object." Mourning is triggered by a loss that has really happened, whereas in melancholia the person does not know certainly what she has lost, or what she is deprived of in losing the other. That is why Freud (1917, p. 254) defines melancholic loss as "an object-loss which is withdrawn from consciousness" or an "unknown loss". Melancholic, without knowing what she is mourning for, not only loses the capacity to love but also loses all her interest in the external world. From its outset, Safe indicates to Carol's melancholic state by introducing her as indifferent, detached and disinterested. Carol's mother is absent in the film however, although at its beginning she gets a phone call from her. During the conversation, the mother's voice is not heard and Carol sounds dismissive and repeatedly says that she and her family are fine. The film does not reveal anything about the nature of their relationship, we do not know whether the two are close or not or whether Carol feels neglected by her mother or not. Carol's ambiguous relation to her mother reinforces her melancholic disposition. Although she says she is fine, Carol goes through a crisis in life and suffers from an undiagnosed illness. As her condition gets worse, she sees her physician who runs some tests. When all the tests come back negative, the physician refers her to a psychiatrist. Yet Carol believes that her problems are not psychosomatic and stops seeing the psychiatrist after meeting him once. As the film unfolds, she is convinced that her problems, uneasiness and attacks are because of an environmental illness that occurs when someone is exposed to toxins or substances in the environment.

The film opens with a sneeze, foreshadowing more problems to come for our protagonist. We first meet Carol underneath her husband in cold, loveless lovemaking. We infer from the detached look on her face that she barely endures having sex with her husband. Carol has a wealthy, sterile, luxurious Southern California life. Even her last name, White, resonates with the clean, sterile, perfect life she has. ${ }^{2}$ She has a loving husband, a stepchild, a beautiful home, and the perfect socialite environment. After the claustrophobic atmosphere of the sex scene, in the next scene she looks like she is trapped among three uniformed men delivering her new couch. In this scene, Carol is at the very background on the left and is hardly seen behind these three men whose positions in the screen make a triangle circling Carol's body. Hidden in the corners of the frame, she is framed among these men from which there is no escape. The big rooms of the house are so enormous and alien to her body. Until her unbearable affliction is manifested, a minor crisis happens when the furniture store delivers the wrong color couch, black rather than teal. Carol is extremely irritated by the presence of the couch which is like a stain in her sterile, cold, symmetrically decorated, ultra-modern house. The black sofa needs to be removed immediately as it stands like a malicious stain in this pure whiteness.

In Chromophobia (2000), while problematizing and providing a cultural criticism of color from the perspectives of art theory, aesthetics and also analyzing popular culture products from cinema to television, David Batchelor gives a special emphasis on the color white. He writes, "Pure white: this is certainly a Western problem [...]" (Batchelor, 2000, p. 13). Pure white is tyrannical and oppressive as it signifies moral purism. In Safe, all the walls in the whole house are white. The uniformity of whiteness swallows up Carol's body. This is a "kind of whiteness that repels everything that is inferior to it, and that is almost everything" (Batchelor, 2000, p. 10). The great white interior of the house purges everything that does not belong to itself. This white is pure, as Carol desires her life to be pure; this whiteness rejects every stain, anything black or any color. According to Batchelor, this white space is analogous to the ideal body:

This space [is] a model for how body ought to be; enclosed, contained, sealed. The ideal body: without flesh of any kind [...] not a place for fluids, organs, muscles, tendons and bones all in a constant precarious and living tension with each other, but a vacant hollow, white chamber, scraped clean, cleared of any evidence of the grotesque embarrassment of an actual life. (Batchelor, 2000, p. 19)

This is almost exactly what describes the body purified from the abjection. "No smells, no noises, no color [...] no exchanges with the outside world and the doubt and the dirt that goes with that, no eating, no drinking, no pissing, no shitting, no sucking, no fucking, no nothing" (Batchelor, 2000, p. 19). This is akin to the urge for ultimately purified, "clean and proper" body described by Julia Kristeva. Thus, Carol's body, in these white interiors, has to fulfill the function of this impossible, ideal body. She wants her body enclosed, contained and does not want it to merge with the world outside.

In the film, Carol's house and the rooms are important in another respect as well as the theme of whiteness. Because of the decoration constantly going on the in the house, there are always men working. The rooms and the whole house are intruded upon all the time. In terms of unconscious symbolism, the houses and the

\footnotetext{
2 In her article, “'It's Just Not Turning Up': Cinematic Vision and Environmental Justice in Todd Haynes's Safe” Nicole Seymour analyzes the film and the issue of whiteness in regard to the operations of "environmental racism and classism" (Seymour, 2011, p. 28). Her article, informed by an ecocritical perspective, engages with "the bodies at the literal and figurative margins of the film-bodies which happen to be lower class and nonwhite" (Seymour, 2011, p. 27). She argues that "Safe (...) links the (in)visibility of envirohealth concerns to dominant racial and class hierarchies, in addition to those of gender (Seymour, 2011, p. 28).
} 
rooms are quite significant. In The Interpretation of Dreams, as Freud (1900, pp. 157-471) states: "[D]reamimagination has one particular favorite way of representing the organism as a whole: namely as a house. [...] separate portions of a house may stand for separate portions of the body" [...] "Rooms in dreams are usually women." So, the house can be said to represent Carol's body. She is disturbed because of the house's intrusion by men. She loathes their being all around the house, because she feels like her body is being invaded by them.

In the following scene, she wakes up to the sound of the alarm and finds herself in the middle of the decoration work. All over the film, we constantly hear every day sounds such as the clock, radio, television etc. Most of the time, Carol sleeps or indulges in a catatonic state and these noises call her back to the reality she is escaping from. There is also a low-level noise on the soundtrack indicating that some sort of machinery or engine (such as air conditioning or an electrical motor) is always at work. These are again the call of reality. In the middle of all these noises made by decoration workers, she barely sits on a chair and tries to breathe. Again, if we think of the house symbolism above, we can say that she feels like her body is intruded. She is in the middle of the frame and stares directly towards the camera. She drinks milk, as she always does. She does not have an appetite and rarely eats yet milk, this maternal food, soothes her like the sip of an alcoholic drink calms an alcoholic. Then, she freezes in a catatonic moment and she is detached from all her environment.

In the next scene, Carol is caught in traffic behind a truck discharging nasty fumes. She starts coughing uncontrollably and has to pull over in a parking garage. In the traffic jam, there are big trucks driven mostly by men. In fact, she coughs not because of the fumes but of the male dominance surrounding her. This is further emphasized later in the film where she has another attack when she is encountered by two muscular men working at the dry-cleaning place. Later, at a dinner with her husband's friends, one of the men starts to tell an obscene joke about a woman who has a surgery because her vibrator gets stuck while using it. In this scene, Carol closes her eyes as she does not want to hear anything about sex and again falls into a catatonic state. She wants to be completely detached from sexuality. In the following scene, when they are having dinner, her stepson reads his homework on the gangs in Los Angeles, in the 80s. He talks about the rapes, riots and shootings in the area. Carol looks at him with repulsion and says "why does it have to be so gory?" She wants to be isolated from the all realities of life, especially when it comes to sex and violence. She does not want any blackness in her absolute white world. She does not want any stain, dirt or flaw in her life.

Carol often experiences catatonic paralysis or seizures which indicate her troubled relationship to corporeality. In the scene at a beauty salon after she gets a perm, Carol reacts extremely when her nose bleeds. In the beauty salon, the reminders of the corporeal such as nails, hair and blood are plenty. In The Beauty Industry, Paula Black (2006, p. 48) states that the beauty salon is the site where "the boundaries of an 'acceptable' bodily state" is maintained. In Kristevan sense, corporeal practices engaged in beauty salons can be considered as akin to exclusionary rituals. Borderline elements that are associated with the maternal body or corporeality are codified as abject and through ritualistic activities these are expelled so that the clean and proper body is sustained. The problem of demarcation, and the issue of borders more broadly, are central to Kristeva's abjection, which is delineated as "what does not respect borders, positions, rules" and "what disturbs identity, system, order" (Kristeva, 1982, p. 4). Kristeva writes, "[A]bjection assumes specific shapes and different codings according to the various symbolic systems" (Kristeva, 1982, p. 68). Considering different social or religious contexts, abjection has taken various names such as exclusion, taboo, transgression or sin.In her article, The Body of Signification,Elizabeth Grosz (1989, p. 89) explains Kristeva's proposal as, "three broad categories of abjects, against which various social and individual taboos are erected: food, [corporeal] waste and the signs of sexual difference [...]" In each category, an element becomes abject as long as it resides on the boundary between two different entities or terrains. Kristeva writes that "we may call it a border; abjection is above all ambiguity" (Kristeva, 1982, p. 9). Preceding binary codings, the abject demonstrates the impossibility of clear-cut borders and lines of delimitation. Borderline elements (skin, nails or hair), and the corporeal wastes (feces, blood, urine, or pus) evoke the sense of abjection because they point to the border demarcating "the clean and proper body" from "the abject body." "The fully symbolic body must bear no indication of its debt to nature" (Creed, 2002, p. 67). In Kristeva's words, the symbolic body should cut off its relation to "the unclean" and "the non-symbolized" (Kristeva, 1982, p. 102). In this respect, the beauty industry - which is operative in reforming or modifying the corporeal bordersengages with and rehabilitates the unstable boundaries and thus, assumes/fulfills the role of rituals in the modern society.

In this context, the beauty salon functions to remove the reminders/traces of the unclean, non-symbolized body, to stave off the corporeal processes and also mask their very manipulation in such a sacred/exclusive environment. In these salons, the customers get haircuts, manicures, pedicures, facials and wear beauty masks. In the same way that rituals are operative for so-called "primitive" people, these procedures 
provide the modern subject the confirmation that corporeal elements are warded off. However, for Kristeva, "the foundations of the symbolic construct" as well as "the limits of the speaking being" are not stable, but brittle, since it is never possible to conclusively wipe out or exclude the improper, the unclean, and the anti-social (Kristeva, 1982, p. 18). Due to the paradoxical logic of their existence, these disorderly elements can never be conclusively eliminated, as the very process of exclusion is what founds the boundaries between the pure and impure, what is clean and what is unclean/filth. The social symbolic is founded on the exclusion of what is jettisoned from its borders, the abject; through such exclusion, its very boundaries are erected and maintained. In this respect, the paradoxical logic of abjection is twofold: it entails an ongoing process that is impelled by the need to designate the abject material, yet the very material codified as abject in return threatens the identity/unity of the subject and the social order. Delving into the fragile borders of subjectivity, Kristeva reveals the subject as one who is in process or on trial, whose constitution is never complete because the abject is completely ineliminable. As a borderline case, Carol's own corporeal borders are not solidly, firmly constituted. For her, these procedures at the beauty parlor do not serve the function that they fulfill for the customers. Indeed, when having a perm, she recognizes the fragility of her own borders; she feels abjected and gives in to the attacks of the reminders of the corporeal. Thus, what gives her nosebleeds is not the smell of the perm but the process that takes care of her nails and hair, borders of her body.

After she comes home, her husband makes a comment about how sexy her new hair style is and wants to have sex with her. There is another point which is crucial about the theme of hair. In The Interpretation of Dreams, while Freud is explaining the workings of some typical dreams, he writes as follows:

\section{[...] the frequency with which sexual repression makes use of transportations from lower to an upper part of the body. [...] Comparison between nose and the penis are common, and the similarity is made more complete by the presence of hair in both places. (Freud, 1900, pp. 509-510)}

Thus, we can also assert that she panics and her nose bleeds when she looks at her new look in the mirror since her hair is the reminiscent of her pubic hair. She does not want to be reminded of her genitals, her sexuality at all. This symbolization becomes clearer when her husband says that her hair is sexy. That night when she does not want to have sex, her husband, Greg, is pissed off. Next morning, when they attempt to reconcile with a hug, she begins to shake, pushes away from Greg, and then, she vomits on the floor. Elizabeth Grosz (1989, p. 89) explains the one's reaction to abjection is “[...] usually expressed in retching, vomiting, spasms, choking - in brief, in disgust. These reactions [...] represent a body in revolt, a body disavowed by consciousness which it is yet unable to ignore." Carol's body revolts, repels and rejects as she struggles with the instability of her corporeal borders. She throws up since the reaction to the feeling of abjection is the repetition of abjection. Throwing up is a way of warding off abjection by repeating the abject itself. When vomiting, we spit ourselves out:

I spit myself out, I abject myself within the very same motion through which 'I' claim to establish myself. [...] that trifle turns me inside out, guts sprawling; [...] 'I' am in the process of becoming another at the expense of my own death. I give birth to myself amid the violence of sobs, of vomit. (Kristeva, 1982, p. 3)

When we throw up, we are turned inside out; the borders of the body are threatened. Carol feels abjected since she does not want to have sex with her husband. In the act of intercourse, the two bodies incorporate, becoming one. Thus, sexual intercourse threatens the borders between oneself and the other.

Here it should be noted that Carol's trials with corporeality also demonstrates itself in her relation to orality and eating. As aforementioned she rarely eats; as the film progresses, she eats less and less and she loses weight. She becomes so skinny that she looks like she can barely stand. When the allergy tests are run, she reacts to milk and gives into another attack at the lab. Milk signifies not only the mother's food but also her love, rejecting this food is refusing the maternal love. Kristeva writes: "When the eyes see or the lips touch that skin on the surface of milk-harmless, (...) I experience a gagging sensation" (Kristeva, 1982, pp. 2-3). Food is ambiguous and it becomes abject when it stands in and signifies the boundary between oneself and the (m)other. That is why Kristeva underlines that food loathing is the "most archaic form of abjection" (Kristeva, 1982, p. 2). Carol, suffering from melancholia, having an ambiguous relation to the maternal, is both repelled and fascinated by milk. Milk soothes her but also when it is injected into her body, she cannot breathe and she has an attack.

Later, Carol has another attack when a little girl sits on her lap at one of her friends' baby shower. The little girl's sitting in her lap again causes the feeling of abjection in her. The image of her body integrated with the other body of the little girl again threatens the borders; the borders between 'I' and the other are almost erased. The indistinguishability of these two bodies is emphasized visually via Carol's and the little girl's similar facial features, hairdo and clothing. The whole event, the baby shower, in fact causes abjection in 
her, there is a pregnant woman around and she is the source of abjection. In Desire in Language: A Semiotic Approach to Literature and Art, Kristeva comments on the pregnancy as follows:

Cells fuse, split, and proliferate; volumes grow, tissues stretch, and body fluids change rhythm, speeding up or slowing down. Within the body, growing as a graft, indomitable, there is an other. And no one is present, within that simultaneously dual and alien space, to signify what is going on. It happens, but I'm not there. I cannot realize it, but it goes on. Motherhood's impossible syllogism. (Kristeva, 1980, p. 237)

For Kristeva a pregnant woman is not a subject and maternity is a process where there is neither yet a subject nor an object. The pregnant body is one of the most abject images since the differentiation of one body from another is not accomplished. The feeling of abjection is caused when the firmness of the borders demarcating internal/external and subject/object are made unstable (Kristeva, 1982, p. 53).

Carol rejects sexuality since she does not want to integrate to the symbolic life at all. For her, the sexual act seems like a deed of violence against her fragile borders. She hardly fills a definite position in the sociosymbolic network, as she does not meet the requirements of a marriage, such as performing sex or having a baby. Carol gradually regresses to the pre-Oedipal paradigm in which the infant is integrated with the maternal body. The archaic, maternal authority-which is linked to the semiotic and corporeal-is repressed in order for language and paternal authority to be established. Therefore, paternal authority is an order of secondary repression that represses the maternal authority and its semiotic capacities-through which the boundaries of the infant's body are already organized and demarcated. Carol's abjection, her incapacity to accept her own corporeal borders, is also apparent in her relation to spatiality as abjection is all about borders and spatial ambiguity. In one scene, when she is in bed, writing a letter responding to the flier that she saw at the health club, her husband comes in and asks how she is doing. Carol cannot answer, she is utterly confused and suddenly says What is this? Where am I right now? Kristeva mentions that:

Instead of sounding himself as to his 'being,' he does so concerning his place: Where am I? instead of Who am I? For the space that engrosses the deject, the excluded, is never one, nor homogeneous, nor totalizable, but essentially divisible, foldable, and catastrophic. (Kristeva, 1982, p. 8)

Carol is foreign even to her own material/corporeal existence. As a borderline subject, for Carol, what is at stake are the primordial distinctions between what is external and what is internal to her, the division between ego and non-ego. As Kristeva points out, "[t]he abject has only one quality of the object-that of being opposed to I" (Kristeva, 1982, p. 1). Sarah Beardsworth (2004, p. 83) clarifies, "The abject is opposed to the $I$ in the sense that it is the focus of the attempt to secure a space for the ego." As far as borderline subjectivity is concerned, the operations for founding a secure separation between ego and object have not yet begun. In the case of Carol, as specular, objectal identifications and separations are not yet operative, we are confronted with the struggles of - not a desiring subject, but-a borderline subjectivity which is, as Kristeva writes, "not sustained by desire, as desire is always for objects" (Kristeva, 1982, p. 7).

As a borderline case, Carol's relation to language is a challenging one. She rarely speaks and cannot complete her sentences, she is so softly spoken that it is hard to hear her. Carol's discourse is characterized by "a challenge to symbolization" or what Kristeva describes as "infantile semiotization" which represents the flow of semiotic into language and emerges in the discourse of the borderline case (Kristeva, 1982, p. 51). For Kristeva, as Kelly Oliver (1998, p. 130) emphasizes in Subjectivity without Subjects, there should be a "dialectical oscillation" between the semiotic and the symbolic, otherwise no signification is possible. Both elements are indispensable to signification. The semiotic element provides its driving force to the signification; without this bodily/material counterpart, signification cannot be produced. On the other hand, the symbolic element yields the logic, the structure to the signification. ${ }^{3}$ In this respect, I argue that abjection issues come forth as a response to an emerging threat of a collapse of meaning or of signification. In Carol's condition, there is not a working dialectic but a short-circuit between the semiotic and the symbolic aspects of the language. As the film unfolds, she utters less and less words. Subjected to the attacks of the corporeal, Carol gradually fails in using of symbolic communication.

\footnotetext{
${ }^{3}$ In Subjectivity without Subjects, Kelly Oliver writes, "The symbolic is the structure or grammar that governs the ways in which symbols can refer. The semiotic element, on the other hand, is the organization of drives in language. It is associated with rhythms and tones that are meaningful parts of language and yet do not represent or signify something. [...] Kristeva maintains that rhythms and tones do not represent bodily drives; rather bodily drives are discharged through rhythms and tones. [...] The interdependence of the symbolic and semiotic elements of signification guarantees a relationship between language and life, signification and experience, and between body (soma) and soul (psyche)" (Oliver, 1998, pp. 130-1).
} 
Although Carol's doctor finds her perfectly healthy, Carol feels tired, exhausted and weak all the time. Carol believes that she is sensitive to the chemically toxic air, that this environment makes her sick. She is allergic to food and sensitive to dust, smog or smell of a cologne. As her undiagnosed illness worsen, she starts wearing a mask and carrying an oxygen cylinder, and moves into a smaller room in the house which is clean and toxin-free. From this moment on, she no longer has sex with her husband and avoids any physical intimacy with him. Meanwhile, numerous tests are further carried out to determine the extent of her allergies, yet they reveal nothing. After having a severe seizure in a dry-cleaning place, she is hospitalized. Eventually, deciding that she has to remove her body of its toxic load and get clean, Carol moves into the chemical-free, toxin-free environment, Wrenwood, a healing facility out in the desert.

Towards the end of the film, after she goes to Wrenwood Center, where she seeks treatment for her disease, Carol gradually regresses to a narcissistic phase. Here, she just wants to retreat from the whole world. The desert air is clean and unpolluted, but never quite enough. Even the fumes from a passing truck put her in a panic. Wrenwood has a semi-religous philosophy, is run by the guru Peter Dunning who is a chemically sensitive man living with AIDS. He encourages Carol to look into herself. Peter tells her that she, herself, is responsible for her illness. If she wants to get well, she needs to purge away those negative feelings and learn to love herself. As a result, this new-age, semi-religious philosophy leads her to isolate herself from society and she cancels her integration into the socio-symbolic network. This self-indulgence, self-love finally causes her to be trapped in a narcissistic closure.

\section{Conclusion}

Towards the end of the film, Carol does not get any better. In Wrenwood, she moves into a completely sterile igloo-shaped house. From the outside, her windowless, safe house looks like a dome. Inside, it is minimally decorated and the furnishings are limited. The shape of the igloo is quite important for filmic narration where the dome shaped buildings usually symbolize either a sort of microcosm or the mind of a person. Here, it can be suggested that the dome is the symbol of Carol's mind and symbolizes the final point she regresses to: herself. In the depiction of Wrenwood, the set-up of the scenes, the costume and the sound have all the hallmarks of science fiction genre. The science fiction qualities of the film become quite clear towards the end. Wrenwood is in the barren desert; the buildings are minimalist and the costumes are not colorful or varied. The narrative explanation given for this clothing is that the patients are asked to dress moderately. The most important and apparent quality borrowed from science fiction is the sound. Throughout the whole film the soundtrack is reminiscent of this genre. There is a metallic, monotonous music which arouses the expectation in us that a spaceship is about to land or some extraterrestrial organisms are going to show up in a moment.

We hear this sound especially when the film shows the desert and the man who was living in the igloo before Carol. His weird, shaky way of walking-because of his illness-reminds us of an astronaut on the surface of the moon. Moreover, the white cloth covering all of his body, which is shown from very a long shot, also looks like the outfit of a science fiction character. Likewise, Carol's white sports outfit and the oxygen tank she carries around everywhere make her look like an astronaut. Why is this science fiction iconography so prevalent in the film which can be called drama? Here it is vital to reference the Lacanian mirror stage in order to answer this question. Jacques Lacan proposes that ego is formed during the mirror stage where there is a counterpart and a specular image to form the ego. The imaginary relations pertaining to the mirror stage propel this dual relationship. Between the ages of six and eighteen months, the infant is physically uncoordinated; her bodily experience involves a sense of disconnectedness, fragmentedness. When the infant sees and recognizes her reflection in the mirror, she perceives this image as full, complete and coherent. The infant's corporeal experience does not match up with what she sees in the mirror and therefore this moment is a misrecognition rather than a recognition. Thus, the infant's ego is formed on the basis of a misrecognition and she takes up this specular image as its own and internalizes it as an ideal-ego. That is why Lacan calls the mirror stage "the transformation that takes place in the subject when he assumes an image" (Lacan, 1993, p. 34). For Lacan (1993, pp. 34-35), the ego and the object come into being as correlates at the mirror stage, through which the inside/outside distinction and an imaginary sense of spatiality develop. During this stage, what she sees in the mirror-the (m)other-is imagined as an autonomous, coordinated and superior being. As in our collective imagination, we think that other living beings live in more developed, complex and superior lives somewhere in the universe. The extraterrestrial organisms-the others of our culture-is always depicted as more advanced and civilized in the science fiction genre. Thus, the way that the infant at the mirror stage perceives her (m)other as superior is similar to the way we imagine an extraterrestrial to possess capacities that we do not own. Alienated from the socio-symbolic network, as Carol is gradually beset by abjection, she regresses into the topology of the pre-symbolic where a border between $I$ and other is yet to be established. 
At the end, the film once more emphasizes Carol's abjection, her troubled relation to her own corporealborders through her failure in the mirror stage experience. ${ }^{4}$ In the film's final scene, confronting her image in the mirror, Carol addresses herself: "I love you... I really love you... I love you...," she says. Her words are hesitant yet Carol tries to convince herself that she is well. In this scene, the camera is placed where the mirror is. Thus, she directly speaks to the camera and the spectators do not see her reflection as Carol's experience of abjection precedes any recognition of the self. In other words, there is neither a 'specular' counterpart, nor 'correlative' support to her ego to emerge. Eventually, abjection causes Carol to pass to the narcissistic phase. According to Kristeva, abjection precedes narcissism:

Even before being like, I am not but do separate, reject, ab-ject. Abjection ... is a precondition of narcissism. [...] [Abjection] is experienced at the peak of its strength when that subject, weary of fruitless attempts to identify with something on the outside, finds the impossible within; when it finds that the impossible constitutes its very being, that it is none other than abject. (Kristeva, 1982, pp. 15,5$)$

Carol remains trapped in a narcissistic closure which is caused by what Kristeva calls "the abjection of the self" (Kristeva, 1982, p. 5). Over its course, Safe does not disclose the source or the origins of Carol's undiagnosed illness, her undefinable unease, yet it reveals her disturbed relation to the corporeal and to the maternal. Carol who fails to sustain a "clean and proper body" cannot conform to the boundaries rigidly enforced by the socio-symbolic order. Her suffering is that of a borderline subjectivity, as she is abandoned at her own borders as well as at the limits between the individual and society.

\section{References}

Batchelor, D. (2000). Chromophobia. Reaktion Books.

Beardsworth, S. (2004). Julia Kristeva: Psychoanalysis and modernity. State University of New York Press.

Black, P. (2006). The beauty industry: Gender, culture, pleasure. Routledge.

Christian, L. (2004). Of housewives and saints: Abjection, transgression and impossible mourning in poison and safe. Camera Obscura, 19 (3), 93-123.

Creed, B. (2002). Kristeva, femininity, abjection. In K. Gelder (Ed.), The horror reader (pp. 64-70). Routledge.

Freud, S. (1900). The interpretations of dreams. In J. S. Strachey (Ed. \& Trans.), The Penguin Freud library 4 [Reprinted 1991]. Penguin Books.

Freud, S. (1917). Mourning and melancholia. In J. S. Strachey (Ed. \& Trans.), On metapsychology: The theory of psychoanalysis. The Penguin Freud library 11 [Reprinted in 1991] (pp. 245-268). Penguin Books.

Grosz, E. (1989). The body of signification. In J. Fletcherand and A. Benjamin (Eds.), Abjection, melancholia, and love: The work of Julia Kristeva (pp. 80-103). Routledge.

Haynes, T. (Director). (1995). Safe [Motion Picture]. Sony Pictures Classics.

Kristeva, J. (1980). Motherhood according to Giovanni Bellini. In L. S. Roudiez (Ed.), T. Gora, A. Jardine and Roudiez, L. S. (Trans.), Desire in language: A semiotic approach to literature and art (pp. 237-70). Blackwell.

Kristeva, J. (1982). Powers of horror: An essay on abjection (L. S. Roudiez, Trans.). Colombia University Press. Lacan, J. (1993). The Mirror Stage. In A. Easthope (Ed.), Contemporary Film Theory (pp. 33-39). Longman.

Oliver, K. (1998). Subjectivity without subjects. Rowman and Littlefield Publishers Inc.

Seymour, N. (2011). "It's just not turning up": Cinematic vision and environmental justice in Todd Haynes's Safe. Cinema Journal, 50(4), 26-47.

\footnotetext{
${ }^{4}$ For Kristeva, abjection is "logically and chronologically" anterior to the mirror stage. When the abjection looms in the "archaism of pre-objectal relationship," there is not yet a "counterpart" or a "specular" image to form the ego (Kristeva, 1982, pp. 13). Kristeva writes, "[T]he mimesis, by means of which he becomes homologous to another in order to become himself, is in short logically and chronologically secondary" (Kristeva, 1982, pp. 13). Therefore, the attempts to establish a border between 'I' and other, or in a more archaic sense, to set up an inside/outside boundary, begin to appear earlier than the mirror stage. In other words, in Kristevan thought, the primitive ego's experience of a space-the struggle to overcome that spatial ambivalence-predates the mirror experience. Thus, in introducing this pre-imaginary moment of separateness, an archaic moment of pre-symbolic subject-formation, Kristeva departs from the Lacanian perspective.
} 